\title{
RESENHA DA OBRA A PROJEÇÃO DA \\ CONSTITUIÇÃO SOBRE O ORDENAMENTO JURÍDICO, DE FRANCISCO BALAGUER CALLEJÓN ${ }^{1}$
}

Gabriel Dias Marques da Cruz $^{2}$

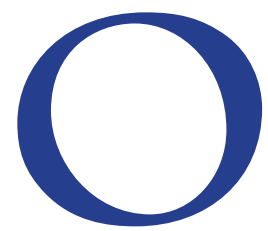

Professor Francisco Balaguer Callejón tem se tornado cada vez mais conhecido no Brasil, tendo publicado diversas obras no País e recebido, inclusive, o título de Doutor Honoris Causa pela Universidade Federal do Maranhão. Atua como Professor Catedrático de Direito Constitucional na Universidade de Granada, na Espanha, assim como é Catedrático Jean Monnet ad personam de Direito Constitucional Europeu e Globalização.

Trata-se de obra traduzida pelo Professor Paulo Roberto Barbosa Ramos, publicada na Linha de Direito Comparado do Instituto de Direito Público de Brasília.

01 BALAGUER CALLEJÓN, Francisco. A projeção da Constituição sobre o ordenamento jurídico. Tradução de Paulo Roberto Barbosa Ramos. São Paulo: Saraiva, 2014 (Série IDP: linha direito comparado). 120 páginas. Título Original: La proyección de la Constitución sobre el ordenamento jurídico. ISBN: 978-85-02-20926-8.

02 Mestre e Doutor em Direito do Estado pela Universidade de São Paulo (USP). Professor de Direito Constitucional da Universidade Federal da Bahia (UFBa), Faculdade Baiana de Direito e Faculdade Ruy Barbosa. E-mail: gabriel_dmc@yahoo.com.br 
A obra encontra-se dividida em seis capítulos, contemplando os seguintes temas: (I) as fontes do direito e dos ordenamentos jurídicos; (II) as normas jurídicas; (III) a constituição; (IV) a lei; (V) o regulamento e a sua relação com a lei; (VI) as fontes do direito e da integração supranacional.

Primeiramente, o autor busca demonstrar a relação existente entre fontes do direito, ordenamento jurídico e pluralidade de ordenamentos. Neste sentido, parte de uma compreensão sobre o significado das fontes do direito, entendendo-as como categorias ou tipos normativos, por meio dos quais são incorporadas normas jurídicas aos ordenamentos. Salienta que apenas seriam fontes do Direito as regras capazes de produzir eficácia erga omnes. Destaca o papel da teoria kelseniana na superação da doutrina tradicional das fontes do direito, promovendo uma passagem do Estado Legal de Direito para o Estado Constitucional de Direito. Após narrar a relevância do conceito de normas sobre a produção jurídica para a compreensão da estrutura e do funcionamento do ordenamento jurídico, salienta o significado do próprio ordenamento como um sistema, distinto das normas que o integram. A seguir, ressalta as características de unidade, coerência e plenitude do ordenamento para, enfim, enfatizar um significativo problema atual: a articulação entre diversos centros de produção normativa em um mesmo ordenamento. Destarte, opera-se mudança significativa na análise das fontes, que precisa acompanhar as mudanças constatadas na própria história do constitucionalismo. Sendo assim, o autor finaliza o primeiro capítulo evidenciando o quanto, atualmente, os conflitos de poder estão mais presentes nas relações entre ordenamentos que na tensão entre fontes de um mesmo ordenamento, o que merece maior atenção da doutrina.

A seguir, o autor examina as normas jurídicas, dedicando atenção a conceitos como validade e âmbitos de validade, eficácia, vigência e legitimidade. Inicia sua abordagem destacando o quanto a norma representa o conceito fundamental do ordenamento jurídico, focando, na sequência, a validade das normas. No particular, descreve a validade como produção normativa em consonância com procedimentos de um ordenamento jurídico. A eficácia, por sua vez, retrataria os efeitos jurídicos previstos pelo ordenamento para a norma, o que varia segundo a fonte do Direito a ela relacionada. O autor mostra a proximidade entre os 
conceitos de eficácia e validade, abordando, ainda, a legitimidade como requisito relevante. Dedica grande atenção ao tema da efetividade, essencial para a validade do próprio ordenamento jurídico. Examina com atenção os âmbitos de validade da norma, trazendo a vigência como correspondência ao âmbito temporal de validade normativo. O autor aborda ainda, neste capítulo, os conceitos de derrogação, o Direito transitório e o Direito intertemporal. Finaliza a análise tratando do princípio da irretroatividade, tratando da clássica diferenciação dos graus de retroatividade mínima, média e máxima como critérios orientadores de enfrentamento da questão.

O terceiro capítulo versa sobre a Constituição, dando destaque inicial para o sistema jurídico da Constituição normativa, que alterou, de modo significativo, o sistema de fontes. Reforça o quanto o ordenamento jurídico das Constituições normativas valoriza o ideal de sistema, situando a Constituição como centro operativo da mudança em prol do Estado Constitucional de Direito. Enfatiza a articulação relevante entre os institutos da rigidez constitucional e da jurisdição constitucional como elementos garantidores da supremacia da Constituição. Mostra, ainda, o quanto os conceitos de normas interpostas e de bloco de constitucionalidade são úteis para a compreensão do pluralismo no sistema de fontes. Encerra o capítulo destacando a relevância da jurisdição constitucional e o seu papel criativo no Direito ante a sua capacidade de inovação.

Na sequência, o autor versa sobre a lei, objeto do quarto capítulo. Trata de sua posição no sistema de fontes, realçando o seu sentido democrático da produção jurídica. Destaca o status especial da lei no ordenamento jurídico ao ocupar um patamar inferior ao da Constituição, embora superior ao do regulamento.

A seguir, no capítulo cinco, o autor trata justamente do regulamento e de sua relação com a lei. Após abordar as diversas classes de regulamentos, comenta a relação específica entre lei e regulamento, enfatizando a primazia legal, corporificada na reserva de lei como elemento chave do Estado de Direito. Na sequência, examina a reserva de lei como maior expressão do sentido constitucional de democracia, aliada à divisão dos poderes. Destaca a extensão do conteúdo da reserva de lei, sendo cabível à lei o delineamento das políticas públicas vinculadas à ação estatal. 
Finaliza o capítulo chamando atenção para o fato de que cada ordenamento concebe de modo distinto a relação entre lei e regulamento.

Por fim, o autor encerra sua obra no capítulo seis, voltado ao exame da relação entre fontes do direito e da integração supranacional. Nota-se, no caso, uma ponte entre o início e o fim de sua abordagem, na medida em que, agora, a normatividade da Constituição é analisada no âmbito dos contextos supranacionais. O autor registra, então, o quanto o advento da União Europeia trouxe novos desafios para o tema, diante dos fenômenos da globalização e da democratização ocorridos após os anos cinquenta do século XX. De modo extremamente cuidadoso, o autor menciona o quanto o Tratado de Lisboa, em vigor desde dezembro de 2009, impactou a lógica tradicional do sistema de fontes, usualmente regido pelos ordenamentos nacionais. Sendo assim, torna-se necessária a construção de um sistema de fontes que seja coerente em relação ao atual desenvolvimento do Estado de Direito. Após toda a análise, o autor finaliza a sua obra com um apelo em prol do desenvolvimento doutrinário de um Direito constitucional supranacional. Tal Direito deve assegurar a aplicabilidade de técnicas constitucionais à nova realidade jurídica verificada, desde que sejam respeitadas as estruturas democráticas e o objetivo de construção de um espaço público plural.

Percebe-se, portanto, que a obra do Professor Francisco Balaguer Callejón traz uma reflexão madura e muito apropriada sobre, em essência, o significado atual da sistemática de fontes do Direito no Direito Constitucional e no contexto de integração supranacional. A temática das fontes do Direito é alvo de antiga atenção do professor, agraciado com o Prêmio Adolfo Posada do Centro de Estudos Constitucionais em 1993 por publicações sobre o assunto. A obra ora resenhada revisita a publicação premiada do autor, que se dedicava ao estudo da Constituição normativa a partir da transição entre os Estados Legal e Constitucional de Direito, para enriquecê-la com uma análise contemporânea, centrada na busca pela construção de um Direito constitucional supranacional.

Recebido em: abr/2015

Aprovado em: jul/2015 